\title{
Self Regulated Learning dan Dukungan Sosial dengan Prokrastinasi Akademik pada Mahasiswa di Masa Pandemi
}

\author{
Suroso ${ }^{1}$, Niken Titi Pratitis ${ }^{1 *}$, Reni Oktaviana Cahyanti ${ }^{1}$, Farra Lailatus Sa'idah ${ }^{1}$ \\ ${ }^{1}$ Fakultas Psikologi Universitas 17 Agustus 1945 Surabaya, Surabaya-Indonesia \\ * corresponding author: nikenpratitis@untag-sby.ac.id
}

\begin{abstract}
Student academic procastination is a tendency to procrastinate in completing assignments so that it results in not completing assignments and even hindering his studies in Higher Education One of the causes of internal factors is the lack of strategy and self-regulation or self-regulation, while external factors that are also predicted to cause procastination are social support. This quantitative study was aimed at examining the relationship between self-regulated learning and social support and academic procrastination during the pandemic. Research respondents were 266 students of all majors from various public and private universities whose data were obtained through the google form scale, which was distributed through social media applications. The data analysis technique used is the non-parametric Spearman Brown technique and the parametric Pearson correlation technique. The results of data analysis showed that there was a significant correlation between self-regulated learning and academic procastination (sig.0.029) but there was no significant correlation between social support and academic procastination (sig. 0.903).
\end{abstract}

Keywords: self regulated learning, social support, academic procastination

Abstrak-Prokastinasi akademik mahasiswa merupakan kecenderungan perilaku menunda-nunda menyelesaikan tugas hingga berakibat tidak terselesaikannya tugas bahkan terhambat studinya di Perguruan Tinggi. Salah satu faktor internal penyebabnya adalah kurangnya strategi dan pengaturan diri atau regulasi diri (self regulated) sementara faktor eksternal yang juga diprediksi dapat menyebabkan prokastinasi adalah, dukungan sosial. Penelitian kuatitatif iniditujukan untuk menguji hubungan antara self regulated learning dan dukungan sosial dengan prokrastinasi akademik dimasa pandemi. Responden penelitian adalah 266 orang mahasiswa semua jurusan dari berbagai universitas negeri maupun swasta yang datanya diperoleh melalui skala google form, yang disebarkan melalui aplikasi media sosial. Teknik analisis data yang digunakan yaitu teknik non parametric spearman brown dan teknik parametric pearson correlation. Hasil analisis data menunjukkan bahwa terdapat korelasi yang signifikan antara self regulated learning dengan prokastinasi akademik $(p=0,029)$ tetapi tidak ada korelasi yang signifikan antara dukungan sosial dengan prokastinasi akademik $(p=0,903)$.

Kata kunci: self regulated learning, dukungan sosial, prokastinasi akademik

\section{PENDAHULUAN}

Masa pandemi covid 19 mengubah situasi belajar di perguruan tinggi dari belajar langsung yang mengharuskan tatap muka antara dosen dengan mahasiswa berubah menjadi belajar secara daring atau PJJ (Pembelajaran Jarak Jauh). Upaya tersebut dilakukan pihak perguruan tinggi sesuai instruksi Menteri Pendidikan dan Kebudayaan yang menekankan SFH (School From Home) untuk semua lini pendidikan, demi mengurangi laju penyebaran virus covid 19. Meski awalnya disambut dengan riang gembira, namun sekarang banyak mahasiswa yang mengeluh banyaknya tugas yang diberikan sebagai pengganti model pelajaran tatap muka, bahkan bagi mahasiswa yang seringkali prokrastinasi, tumpukan tugas online justru menjadi neraka virtual (Sudarko, 2020).

Meskipun jauh sebelum situasi pandemi merebak, kasus prokastinasi dikalangan mahasiswa banyak terekam dalam banyak penelitian (Fauziah, 2015; Muyana, 2018; Ursia, Siaputra \& Sutanto, 2013; Rustam, 2019; Sabatini, 2013; Aini, Noor \& Mahardayani, 2011; Irna, 2014; Putri, Wiyanti, \& Priyatama, 2012), bahkan sebuah riset Diktis yang dimuat dalam sebuah situs online (Arifin, 2019) menyebutkan bahwa di Universitas Negeri Sebelas Maret (UNS) ditemukan prokrastinasi akademik yang tinggi pada mahasiswa Program Studi Psikologi mencapai 13,68 persen. Hal yang sama, juga diungkapkan Arifin (2019) bahwa di Universitas Ibn Khaldun (UIKA) Bogor terekam 2.823 mahasiswa dari 5149 mahasiswa yang aktif di tahun ajaran 2016/2017, terindikasi prokrastinasi. Dikemukakan pula oleh Muyana (2018) dalam penelitiannya bahwa dari 229 mahasiswa Bimbingan Konseling di Universitas Ahmad Dahlan Yogyakarta, 161 diantaranya cenderung tinggi prokastinasinya. 
Di situasi pandemi Covid 19 saat ini pun, peneliti mengamati pula bahwa banyak mahasiswa yang sebelumnya telah menunda-nunda menyelesaikan tugas, makin sering melakukan prokastinasi. Seperti misalnya beberapa mahasiswa S1 di sebuah perguruan tinggi yang cenderung memilih menghabiskan waktu berjam-jam membuka media sosial, bermain gamme online, atau justru mengerjakan pekerjaan lain dibandingkan mengerjakan tugas yang diberikan dosen saat kuliah daring. Salah satu faktor yang menurut Latifah \& Damajati (2018), Steel (2017), Saraswati (2017), Savira \& Suharsono (2013), Alfina (2014), dapat menyebabkan seseorang mahasiswa melakukan prokrastinasi adalah kurangnya strategi dan pengaturan diri atau disebut juga regulasi diri (self regulated). Self regulated learning yang rendah merupakan faktor internal yang dalam beberapa penelitian terbukti berperan menyebabkan prokastinasi akademik. Seperti disebutkan Lailul (2018) bahwa self regulated learning dimiliki individu, maka ia akan belajar secara aktif, menyusun, menentukan tujuan belajar, merencanakan dan memonitor, mengatur dan mengontrol kognisi, motivasi perilaku serta lingkungannya untuk mencapai tujuan yang telah ditetapkan sehingga mendorong kemandirian belajar. Tentunya mahasiswa yang memiliki self regulated learning yang tinggi, akan melibatkan metakognisi, motivasi, dan perilaku mereka dalam belajar dan mencapai tujuan belajar yang diinginkan, sehingga tidak ada penundaan tugas-tugas perkuliahan. Maknanya, individu dengan selfregulated learning yang tinggi akan mampu mengatur dan membagi aktivitas-aktivitasnya dalam waktu dan proporsi yang tepat sesuai dengan prioritas dan kepentingannya, sehingga teselesainya pekerjaan atau aktivitasnya sesuai waktu yang ditetapkan dan merasa bahagia karena mampu menepati jadwal yang direncanakannya untuk menyelesaikan tugas.

Selain self-regulated learning, dukungan sosial juga menjadi salah satu faktor yang mempengaruhi prokrastinasi (Putri, 2014; Fibrianti, 2009; Lubis, 2018; Safitri, 2018; Rini, 2009). Dukungan sosial yang merupakan faktor eksternal yang mempengaruhi prokastinasi akademik, menurut Gibson (2005) merupakan kesenangan, bantuan yang diterima seseorang melalui hubungan formal dan informal dengan yang lain atau sekelompok, yang menurut Arfiansah (2019) mengacu pada penerimaan rasa aman, peduli, penghargaan atau bantuan yang diterima seseorang dari orang lain atau kelompok. Adanya dukungan sosial, menurut Rini (2009) dapat membuat individu meras memperoleh perhatian, sehingga individu memiliki kemantapan diri yang baik serta memiliki sikap yang dapat menerima kenyataan, dapat mengembangkan kesadaran diri, berfikir positif, memiliki kemandirian, dan mempunyai kemampuan untuk memiliki serta mencapai segala sesuatu yang diinginkan, termasuk dalam menyelesaikan tugas-tugas.

\section{METODE}

Penelitian kuantitatif ini menggunakan dua teknik analisis data parametric dan non parametric. Teknik analisis non parametrik Spearman Brown digunakan untuk menganalisis hubungan dukungan sosial dengan prokastinasi akademik karena sebaran data skornya berdistribusi normal tetapi tidak linier. Sementara untuk analisis korelasional antara selfregulated learning dengan prokrastinasi akademik digunakan teknik parametric Pearson Correlation.

Responden penelitian ini adalah 266 orang mahasiswa yang berstatus aktif kuliah secara online, di semua jurusan dari berbagai perguruan tinggi negeri / swasta. Data responden diperoleh melalui 3 skala yang dirancang peneliti sendiri, yaitu skala Prokastinasi Akademik, skala Self Regulated Learning dan skala Dukungan Sosial. Ketiga skala telah teruji validitas dan reliabilitasnya.

Skala Prokastinasi Akademik secara konseptual didasarkan pada aspek-aspek prokastinasi akademik dari Ferrari (1995), sedangkan skala self-regulated learning didasarkan pada konseptual Zimmerman (1989) dan skala dukungan sosial menggunakan landasan aspek teoritis Safarino (2012). Validitas dan reliabilitas skala penelitian dibuktikan dari 2 cara, yaitu bukti berdasarkan struktur internal alat ukur (yaitu didasarkan pada index corrected item correlation dalam uji diskriminasi aitem) dan bukti berdasarkan isi alat ukur (yaitu berdasarkan 
Corellation Validity Index dan Correlation Validity Ratio menggunakan rumus Aiken' Index). Berikut rangkumannya :

Tabel 1

Rangkuman Evidensi Validitas dan Reliabilitas Skala Penelitian Berdasarkan Struktur Internal Alat Ukur

\begin{tabular}{lllll}
\hline Skala & $\begin{array}{l}\text { Jumlah Aitem } \\
\text { Awal }\end{array}$ & $\begin{array}{l}\text { Jumlah Aitem } \\
\text { Valid }\end{array}$ & Reliabilitas & $\begin{array}{l}\text { Corrected Item Total } \\
\text { Correlation }\end{array}$ \\
\hline $\begin{array}{l}\text { Prokastinasi } \\
\text { Akademik }\end{array}$ & 40 & 28 & 0,916 & $0,338 \mathrm{~s} / \mathrm{d} 0,722$ \\
$\begin{array}{l}\text { Self Regulated } \\
\text { Learning }\end{array}$ & 40 & 29 & 0,907 & $0,320 \mathrm{~s} / \mathrm{d} \mathrm{0,715}$ \\
$\begin{array}{l}\text { Dukungan } \\
\text { Sosial }\end{array}$ & 40 & 30 & 0,91 & $0,303 \mathrm{~s} / \mathrm{d} \mathrm{0,612}$ \\
\hline
\end{tabular}

Sumber : Output SPSS Seri 20 IBM for Windows

Tabel 2

Rangkuman Evidensi Validitas dan Reliabilitas Skala Penelitian Berdasarkan Isi Alat Ukur

\begin{tabular}{llllll}
\hline Skala & Indeks & Kejelasan & Relevansi & Kesesuaian & Signifikansi \\
\hline Prokastinasi & V'Aiken & $0,63 \mathrm{~s} / \mathrm{d} 1,00$ & $0,69 \mathrm{~s} / \mathrm{d} 1,00$ & $0,69 \mathrm{~s} / \mathrm{d} 1,00$ & 0,81 \\
Akademik & CVR & 0,82 & 0,86 & 0,83 & $\mathrm{P}<0,05$ \\
SRL & V'Aiken & $0,63 \mathrm{~s} / \mathrm{d} 1,00$ & $0,69 \mathrm{~s} / \mathrm{d} 1,00$ & $0,75 \mathrm{~s} / \mathrm{d} 1,00$ & 1,00 \\
& CVR & 0,80 & 0,88 & 0,87 & $\mathrm{P}<0,05$ \\
\multirow{2}{*}{ DukSos } & V'Aiken & $0,50 \mathrm{~s} / \mathrm{d} 1,00$ & $0,75 \mathrm{~s} / \mathrm{d} \mathrm{1,00}$ & $0,63 \mathrm{~s} / \mathrm{d} 10,00$ & 0,81 \\
& CVR & 0,83 & 0,91 & 0,89 & $\mathrm{P}<0,05$ \\
\hline
\end{tabular}

Sumber : Output Excel Program Perhitungan V'Aiken dan CVR

HASIL

Hasil analisis data Pearson's correlation atau product moment, menunjukkan adanya korelasi negatif yang signifikan antara variabel self regulated learning dengan prokrastinasi akademik $\left(r_{x y}=-134 ; p=0,029\right)$. Artinya self regulated learning memiliki hubungan negatif yang signifikan dengan prokrastinasi akademik. Hasil tersebut membuktikan bahwa hipotesis yang menyatakan ada hubungan negatif antara self regulated learning dengan prokrastinasi akademik, diterima atau terbukti. Hasil analisis juga menginformasikan bahwa sumbangan efektif variabel self regulated learning terhadap prokrastinasi akademik pada mahasiswa di masa pandemi sebesar $\mathrm{R} 2=0,018(1,8 \%)$.

Berdasarkan hasil analisis data Spearman Brown atau Spearman Rho ditemukan ada korelasi negatif namun tidak signifikan antara dukungan sosial dengan prokrastinasi akademik, ( $r$ o $=-0,007 ; p=0,903$ ). Artinya dukungan sosial memiliki hubungan negatif namun tidak signifikan (atau dapat diartikan tidak ada hubungan) dengan prokrastinasi akademik. Maknanya, hipotesis penelitian yang menyatakan bahwa ada korelasi negative antara dukugan sosial dengan prokrastinasi akademik pada mahasiswa di masa pandemi tidak diterima. Secara statistik deskriptif, juga dapat digambarkan bahwa prokastinasi akademik responden penelitian yang diatas rata-rata (mean $=82,74$ ) mencapai 142 dari 266 orang responden (53,38\%). Hal ini membuktikan bahwa lebih dari lima puluh persen responden penelitian cenderung diatas rata-rata prokastinasinya.

\section{BAHASAN}

Indikasi bahwa mahasiswa banyak melakukan prokastinasi jauh sebelum pandemi Covid 19 berlangsung, telah banyak dibuktikan dalam berbagai penelitian (Fauziah, 2015; Muyana, 
2018; Ursia, Siaputra \& Sutanto, 2013; Rustam, 2019; Sabatini, 2013; Aini, Noor \& Mahardayani, 2011; Irna, 2014; Putri, Wiyanti, \& Priyatama, 2012). Ternyata di situasi pandemi Covid 19 seperti saat ini pun, prokastinasi akadimik mahasiswa masih tetap terjadi. Hal ini terekam dari hasil analisis data responden penelitian ini yang 53,38\% diantaranya cenderung diatas rata-rata prokastinasi akademiknya.

Banyaknya mahasiswa yang melakukan prokastinasi akademik, menunjukkan bahwa dalam situasi pandemi Covid 19 dengan model pembelajaran daring pun, justru kesadaran mahasiswa untuk tidak menunda-nunda mengumpulkan tugas-tugas akademik mereka, tetap rendah. Situasi belajar daring justru membuat mahasiswa tidak menyegerakan mengumpulkan tugas karena meskipun dalam aplikasi pengumpulan tugas dibatasi waktu, tetapi seringkali mahasiswa masih diberi kesempatan upload tugas ketika menyatakan alasan belum upload tugas tersebut karena terkendala sinyal. Banyak kasus di lapangan terjadi, banyaknya tugas yang diberikan dosen dalam masa perkuliahan daring ini, justru membuat sebagian besar jadwal tugas menumpuk sehingga mahasiswa menjadi bingung mengatur waktu penyelesaiannya, yang ujung-ujungnya berakibat banyak tugas yang tidak dapat selesai tepat waktu. Belum lagi keterbatasan pemahaman saat proses belajar daring yang membuat mahasiswa belum sepenuhnya menyerap pengetahuan yang diajarkan tetapi tetap dituntut mampu menyelesaikan tugas-tugas akademiknya. Hal ini tentu saja menyebabkan mahasiswa merasa tidak sepenuhnya yakin akan kemampuannya menyelesaikan tugas sehingga memilih menunda mengerjakan tugas sebelum benar-benar mengerti tentang materinya.

Tingginya prokastinasi akademik mahasiswa yang belajar secara daring pada saat pandemi ini, berdasarkan penelitian terbukti dipengaruhi secara signifikan self regulated learning. Hal tersebut mendukung hasil-hasil penelitian sebelumnya (Lay, 1993; Savira \& Suharsono, 2013; Alfina, 2014; Steel, 2017; Saraswati, 2017; Latifah \& Damajati, 2018; Santika \& Sawitri, 2016), bahwa prokrastinasi akademik yang dimaknai menunda mengerjakan tugas akademik, dapat dikurangi dengan dimilikinya self regulated learning.

Dimilikinya self regulated learning pada diri mahasiswa, membuat mereka mampu belajar secara aktif, menyusun, menentukan tujuan belajar, bahkan merencanakan dan memonitor, mengatur dan mengontrol kognisi, motivasi perilaku serta lingkungannya untuk mencapai tujuan yang telah ditetapkan sehingga mendorong kemandirian belajar (Lailul, 2018). Jika hal tersebut terjadi, maka kemungkinan prokastinasi tidak akan terjadi, karena mahasiswa akan melibatkan metakognisi, motivasi, dan perilaku mereka dalam belajar dan mencapai tujuan belajar yang diinginkan, sehingga tidak ada penundaan tugas-tugas perkuliahan. Mahasiswa dengan self-regulated learning yang tinggi akan mampu mengatur dan membagi aktivitas-aktivitasnya dalam waktu dan proporsi yang tepat sesuai dengan prioritas dan kepentingannya, sehingga teselesaikannya pekerjaan atau aktivitasnya sesuai waktu yang ditetapkan, yang berefk mahasiswa yang bersangkutan merasa bahagia karena mampu menepati jadwal yang direncanakannya untuk menyelesaikan tugas.

Selain self regulated learning, faktor dukungan sosial sebenarnya cukup berperan dalam meminimalisisr terjadinya prokastinasi akademik sebagaimana hasil penelitian Fibrianti, (2009); Rini (2009); Putri (2014); Lubis (2018); dan Safitri (2018). Tetapi berdasarkan penelitian ini, justru meskipun benar dukungan sosial berpengaruh negatif terhadap prokastinasi akademik, tetapi korelasinya tidaklah signifikan. Artinya adanya dukungan sosial yang kuat pada beberapa mahasiswa hal itu mampu membuat mereka tidak prokastinasi akademik, tetapi pada beberapa mahasiswa lainnya justru membuat mere semakin prokastinasi akademik.

Secara umum, berdasarkan penelitian-penelitian sebelumnya, dukungan yang berupa kesenangan, bantuan yang diterima seseorang melalui hubungan formal dan informal dengan yang lain atau sekelompok orang (Gibson, 2005), akan menimbulkan rasa aman, peduli, penghargaan atau bantuan yang diterima seseorang dari orang lain atau kelompok (Arfiansah, 2019). Adanya dukungan sosial, membuat mahasiswa merasa memperoleh perhatian, sehingga individu memiliki kemantapan diri yang baik serta memiliki sikap yang dapat 
menerima kenyataan, dapat mengembangkan kesadaran diri, berfikir positif, memiliki kemandirian, dan mempunyai kemampuan untuk memiliki serta mencapai segala sesuatu yang diinginkan, termasuk dalam menyelesaikan tugas-tugas (Rini, 2009).

Bahkan menurut Lubis (2018) bahwa sumber-sumber dukungan sosial yang banyak diperoleh individu dari lingkungan seperti orang tua, teman sebaya, guru dan lainnya, dapat memberikan informasi terkait dengan hal yang harus dilakukan jika mengalami hambatan penyelesaian tugas. Selain itu, motivasi atau dukungan moril dari lingkungan sosial individu, dapat pula mendorong individu memilih cara-cara yang memudahkan dalam mengerjakan tugas-tugas dan menyelesaikannya tepat waktu atau tidak melakukan prokastinasi akademik. Adanya dukungan sosial, seharunya dapat memunculkan kenyamanan psikis dan emosional sehingga mahasiswa tidak merasa kesulitan dalam menyelesaikan tugas-tugas akademiknya sehingga memanfaatkan waktunya secara efektif hingga mampu memenuhi deadline pengumpulan tugas-tugasnya.

Namun, kenyataannya pada responden penelitian ini, sebagian besar justru menunjukkan bahwa dukungan sosial yang mereka terima ternyata membuat mereka justru melakukan prokastinasi akademik. Agaknya hal ini terkait dengan perasaan nyaman berlebihan yang dirasakan mahasiswa saat menerima dukungan sosial dari lingkungan atau keluarganya. Kenyamanan yang berelebihan tersebut membuat mahasiswa terlena sehingga merasa tidak perlu menyegerakan segala urusan yang terkait dengan penyelesaian tugas. Karena meski tugas-tugas tersebut belum mereka selesaikan, keluarga tetap akan memberikan dukungan dan kenyamanan secara psikologis tetap mereka dapatkan.

Mahasiswa yang menerima dukungan sosial yang kuat, juga sangat mungkin justru menjadi tergantung dengan dukungan sosial yang mereka terima tersebut. Akibatnya ketika harus menyelesaikan tugas-tugas akademiknya, mereka malah mengandalkan bantuan keluarga atau orang lain dalam lingkup sosialnya untuk membantu mereka. Baik bersifat informasional maupun dukungan instrumental. Terlalu menggantungkan diri pada bantuanbantuan yang membuat mahasiswa merasa nyaman tersebut, membuat mahasiswa pada akhirnya 'menyerahkan' sepenuhnya urusan tugas-tugas pada orang lain, sehingga tidak melakukan kontrol waktu maupun kualitas hasil. Maka, ketika waktu pengumpulan sudah dekat dan mereka baru menyadarinya, bisa jadi tugas itu belum sepenuhnya selesai atau selesai dengan tidak sesuai harapan, sehingga tidak menutup kemungkinan menuntut mahasiswa tersbut kembali memperbaiki atau mengubahnya, sehingga pada akhirnya justru melewati batas waktu.

Terutama di masa pandemi Covid 19 yang menuntut dilaksanakannya pembelajaran daring dimana mahasiswa harus dihadapkan pada kondisi banyak dosen yang memberikan tugas akademik sebagai upaya membuat mahasiswa paham tentang materi yang disampaikan. Namun, alih-alih mahasiswa paham dengan materi yang disampaikan, justru kejenuhan yang lebih sering muncul. Kondisi jenuh dan bosan yang terjadi, tentu memicu pemakluman, pemaafan, pengertian dari anggota keluarga atau orang-orang di lingkungan sosial mahasiswa ketika kemudian mahasiswa 'istirahat sejenak' dari semua tugas yang menghimpit. Bahkan tak jarang orang tua karena kasih sayang yang besar pada anaknya yang kuliah dari dan meresa kelelahan atau bosan, kemudian justru mengadakan kegiatan bersama dalam keluarga untuk memberikan hiburan. Tentu ini merupakan bentuk dukungan sosial yang sangat baik bagi mahasiswa dalam mengatasi kejenuhan belajar secara daring, tetapi disisi lain juga dapat berdampak negatif. Terutama ketika mahasiswa tersebut kemudia lebih banyak memilih melakukan aktivitas-aktivitas menyenangkan bersama keluarga dibandingkan kembali menyibukkan diri dengan tugas-tugas perkuliahan. Akibatnya, prokastinasi akademiklah yang terjadi. 


\section{SIMPULAN}

Kesimpulan yang dapat ditarik dalam penelitian ini, bahwa prokastinasi akademik masih banyak terjadi di kalangan mahasiswa di masa pandemi Covid 19 yang mengharuskan mahasiswa melakukan pembelajaran daring. Bahkan angka prosentase kecenderungan prokastinasi akademik yang diperoleh dari responden penelitian cukup tinggi (lebih dari 50\%). Penundaan pengengajaan tugas tersebut meliputi penundaan terhadap waktu yang berakibat gagalnya mahasiswa memprediksi waktu pengumpulan tugas dengan baik sehingga mereka gagal menyelesaikan tugas. Prokastinasi akademik mahasiswa juga terjadi karena mahasiswa yang bersangkutan tidak konsisten dalam mematuhi jadwal belajar maupun jadwal penyelesaian tugas yang telah mereka rencanakan yang berakibat pada tidak terselesaikannya tugas-tugas akademik mereka. Keraguan akan kemampuan dan perasaan takut gagal pun menjadi pemicu mahasiswa justru menunda mengerjakan tugas dengan alasan pemahaman yang kurang terkait tugas maupun materi pembelajaran yang menunjang penyelesaiuan tugastugas tersebut.

Prokastinasi akademik juga terbuktui dapat diminimalisir dengan menguatkan self regulated learning. Hal ini dimungkinkan karena dengan self regulated learning yang tinggi, mahasiswa akan mampu membuat perencanaan strategi dalam menyelesaikan tugas-tugas akademiknya, mengatur dirinya untuk fokus mengerjakan tugas dan memonitor perilkaunya sendiri untuk menyelesaikan tugas. Keterbatasan pemehamam yang terjadi saat kuliah daring akibat mahasiswa tidak mampu berinteraksi langsung melalui tatap muka dengan dosen, dapat teratasi ketika mahasiswa memiliki self regulated learning yang tinggi, karena mereka akan memiliki rasa ingin tahu yang tinggi hingga mendorong dirinya melakukan pencarian-pencarian sumber bacaan atau sumber informasi yang mendukung mereka mengerjakan tugas dengan lebih cepat. Mahasiswa dengan self regulated learning yang tinggi akan menyeleksi lingkungan belajarnya dan memanfaatkan lingkungannya dengan baik agar berkontribusi dalam penyelesaian tugas mereka

Berbeda dengan hasil penelitian sebelumnya yang menyebutkan bahwa dukungan sosial berkorelasi negative dan signifikan dengan prokastinasi akademik, justru penelitian ini membuktikan bahwa dukungan sosial yang diterima responden penelitian berkorelasi negative tetapi tidak signifikan. Hal ini terjadi karena sebagian responden justru merasakan kenyamanan dan berbagai bentuk dukungan sosial yang mereka terima baik dari orang tua maupun orang lain dalam lingkup sosial mereka, membuat mereka merasa terlena dan bergantung pada orang lain yang berujung prokastinasi akademik.

\section{PUSTAKA ACUAN}

Afriansah (2019). Hubungan Antara Regulasi Diri dan Dukungan Sosial Teman dengan Prokrastinasi dalam Menyelesaikan Skripsi pada Mahasiswa Pendidikan agama Islam Fakultas Tarbiyah dan Keguruan Universitas Islam Negeri Sulthan Thaha Saifudin Jambi. Jurnal Pendidikan: Riset dan Konseptual, Vol.3, No. 2.

Anisahwati, P (2016). Pengaruh Perfectionism dan Dukungan Sosial Terhadap Prokrastinasi Akademik dalam Menyelesaikan Tesis dan Disertasi. Tazkiya Journal of Psychology, Vol. 4 No. 1.

Dewi, S.S \& Alfita, L. (2015). Perbedaan Prokrastinasi Akademik Antara Mahasiswa yang Berpacaran dan Tidak Berpacaran. Jurnal Diversita, Vol. 1, No. 1.

Dwi, L., Rahayu, A. (2018). Hubungan Dukungan Sosial dan Self Eficacy dengan Prokrastinasi Akademik Mahasiswa Perantau yang Berkuliah Di Jakarta. IKRAITH-HUMANIORA, Vol. 2, No.2.

Ferrari, J.R., Johnson, J.L \& Mc. Cown, W.G. (1995). Procrastination And Task Viodance. New York : Plenum Press.

Ghufron \& Rini Risnawati, M.Nur. (2010). Teori - Teori Psikologi. Jojakarta : Ar - Ruz Media

Kumalasari, Fani \& Ahyani,L.N. (2012). Hubungan Antara Dukungan Sosial Dengan Penyesuaian Diri Remaja Di Panti Asuhan. Jurnal Psikologi Pitutur. Vol 1, 21-31 
Latifah. (2018). Hubungan Self Regulated Learning dan Self Esteem dengan Prokrastinasi Akademik pada Mahasiswa yang Mengerjakan Skripsi Di Fakultas Ilmu Pendidikan. Jurnal Penelitian Psikologi. Vol. 05 No. 03.

Nugraha, P. (2013). Pengaruh Self Esteem terhadap Motivasi Bertanding Pada Atlet Ukm Sepak Bola Universitas Pendidikan (Skripsi, dipublikasikan). Program Sarjana Universitas Pendidikan Indonesia.

Rini, P.D. (2009). Hubungan Antara Sense of Humor dengan Somatisasi. Skripsi. (Tidak Diterbitkan). Surakarta : Fakultas Psikologi Universitas Surakarta.

Solomon, L.j., \& Rothblum, E.D. (1989). Academic Procrastination: Frequency and CognitiveBehavioral Correlates. Journal of Counseling Psychology. Vol.31. Diakses tanggal 17 November 2009 dari http://all.successcenterohio- state.edu/references/procrastinator _APA_paper.htm.

Steel, P. (2007). The Nature of Procrastination : A Meta-Analytic and Theoretical Review of Quintessential Self-Regulatory Failure. Psychological Bulletin Journal. Vol. 133, No. 1

Ursia, N.R , Siaputra, I.B \& Sutanto, N. 2013. Prokrastinasi Akademik dan Self Control pada Mahasiswa Skripsi Fakultas Psikologi Universitas Surabaya. Makara Seri Sosial Humaniora. Vol. 17, No. 1, hlm. 1-18

Zimmerman, B. J. 1989. A Social Cognitive View of Self-Regulated Academic Learning. Journal of Educational Psychology, Vol. 81, No. 3 , hlm. 329-339.

Zimmerman, B. J., \& Martinez-Pons, M. 1990. Student differences in selfregulated learning: relating grade, sex, and giftedness to self-efficacy and strategy use. Journal of Educational Psychology, Vol. 82, hlm. 51-59.

Sihyati, T.P. 2019. Mengatasi Kebiasaan Menunda Tugas/Prokrastinasi Pada Pelajar. Artikel. Diunduh dari https://www.rakyatpos.com/mengatasi-kebiasaan-menunda-tugas-prokastinasi-pada-pelajar.html/, 3 Agustus 2020

Arifin, S. 2019. Mengatasi Kasus Prokrastinasi Akademik dengan BKG-Pro E-Learning. Artikel. Diunduh dari https://www.nu.or.id/post/read/112135/mengatasi-kasus-prokrastinasiakademik-dengan-bkg-pro-e-learning, 3 Agustus 2020

Arifin, S. 2020. Sering Tunda Pekerjaan, Ini Dampak Prokrastinasi pada Kesehatan Mental Tak baik bila dilakukan terus-menerus. Artikel. Diunduh dari https://www.indozone.id/ life/Z8sDn3/sering-tunda-pekerjaan-ini-dampak-prokrastinasi-pada-kesehatan-mental/ read-all, 3 Agustus 2020

Sudarko, F.N. 2020. Kuliah Online? Awas Diserang Prokrastinasi!. Artikel. Diunduh dari https://gensindo.sindonews.com/berita/2192/1/kuliah-online-awas-diserang-prokrastinasi, 20 April 2020

Rustam, A. (2019). Perilaku Prokastinasi Akademik pada Mahasiswa. Abstrak. Jurnal Bimbingan Konseling FKIP Universitas Syiahkuala, Vol. 4, No. 1. 